\title{
Produção de Farinha de Yacon em Diferentes Épocas do Ano
}

Patche Helena Michel (I), Gilson Parussolo (I,I), Rita Tatiana Busatto $(I, I)$, Janaína Schmitt $(I, I, I, I)$, Lara Franco dos Santos (I), Edi Franciele Ries $(I, I, I, I)$, Vanessa Pires da Rosa $(I, I, I, I)$

(I) UFSM - Universidade Federal de Santa Maria (Linha Sete de Setembro)

\section{Resumo}

Prebióticos como os frutanos e fruto-oligossacarídeos (FOS) estão sendo utilizados, na sua forma isolada ou por meio de alimentos fonte, como ingredientes alimentícios, por razões nutricionais e tecnológicas. O yacon (Smallanthus sonchifolius) é considerado fonte promissora de frutanos e a partir de suas raízes tuberosas é possível obter farinha, aplicável a produtos propiciando benefícios fisiológicos apresentando efeito prebiótico e antioxidante. $\mathrm{O}$ trabalho teve por objetivo avaliar o rendimento e a caracterização físico-química da farinha de yacon processadas em julho de 2013 e março de 2014. Para obtenção da farinha de yacon, as batatas foram sanitizadas, descascadas com faca de aço inox e cortadas em fatias para inativação enzimática para posterior secagem em estufa ventilada com circulação de ar, a $55{ }^{\circ} \mathrm{C} / 14 \mathrm{hrs}$ e posteriormente triturada para obtenção da farinha. Foram realizadas análises de umidade, extrato etéreo, proteína bruta, cinzas, fibra bruta e $\mathrm{pH}$. O rendimento da farinha na produção de julho de 2013 foi de 12,33\%, para as outras análises, umidade esteve em $10,10 \%$, gordura ficou entre $1,00 \%$, proteína bruta de $2,27 \%$, cinzas de $3,22 \%, 3,16 \%$ de fibra bruta e $\mathrm{pH} 4,53$. Para produção de março de 2014 obteve-se um maior rendimento de $11,89 \%$ relacionado ao menor teor de umidade $(8,35 \%)$. As análises físico-químicas resultaram em um valor menor de gordura $(0,48 \%)$, proteína bruta $(0,78 \%)$ e cinzas $(2,27 \%)$, sendo o teor fibra bruta $(3,28 \%)$ e pH $(6,09)$ maior com relação a produção de julho de 2013. A quantidade de água presente na batata in natura, os

\footnotetext{
Referência:

Patche Helena Michel, Gilson Parussolo, Rita Tatiana Busatto, Janaína Schmitt, Lara Franco dos Santos, Edi Franciele Ries, Vanessa Pires da Rosa.Produção de Farinha de Yacon em Diferentes Épocas do Ano. In: Anais do 12을 Congresso Latinoamericano de Microbiologia e Higiene de Alimentos - MICROAL 2014 [= Blucher Food Science Proceedings, num.1, vol.1]. São Paulo: Editora Blucher, 2014. DOI 10.5151/foodsci-microal-165
} 
diferentes cultivares e a variação de tempo/temperatura da secagem do yacon influenciam a umidade da farinha. As diferenças nas concentrações da composição centesimal e de minerais entre os estudos podem ocorrer em função das condições de cultivo como clima, altitude, região e tipo de solo em que a batata foi produzida. $\mathrm{O}$ yacon possui uma grande quantidade de água, o que resultou em pequeno rendimento na produção de farinha tanto para a produção de julho como para a de março, mas estando de acordo com a Portaria $\mathrm{n}^{\circ} 354$ do Ministério da Saúde que estabelece no máximo $15 \%$ de umidade para farinhas. A farinha apresentou-se como fonte de fibra e pode ser incorporada no desenvolvimento de alimentos comumente presentes na mesa do consumidor para agregação de valor nutricional.

Palavras-Chave: Prebiótico, , inulina,, antioxidante Agência de Fomento: 